\title{
Nutrient Concentrations and Yields in Undeveloped Stream Basins of the United States
}

\author{
Gregory M. Clark, David K. Mueller, and M.Alisa Mast
}

\begin{abstract}
Data from 85 sites across the United States were used to estimate concentrations and yields of selected nutrients in streams draining relatively undeveloped basins. Flowweighted concentrations during 1990-95 were generally low with median basin concentrations of $0.020,0.087,0.26,0.010$, and 0.022 milligrams per liter $(\mathrm{mg} / \mathrm{L})$ for ammonia as $\mathrm{N}$, nitrate as $\mathrm{N}$, total nitrogen, orthophosphate as $\mathrm{P}$, and total phosphorus, respectively. The flow-weighted concentration of nitrate exceeded $0.6 \mathrm{mg} / \mathrm{L}$ in only three basins. Total nitrogen exceeded $1 \mathrm{mg} / \mathrm{L}$ in only four basins, and total phosphorus exceeded $0.1 \mathrm{mg} / \mathrm{L}$ in only four basins. The median annual basin yield of ammonia as $\mathrm{N}$, nitrate as $\mathrm{N}$, total nitrogen, orthophosphate as $\mathrm{P}$, and total phosphorus was $8.1,26,86$, 2.8, and 8.5 kilograms per square kilometer, respectively. Concentrations and yields of nitrate tended to be highest in northeastern and mid-Atlantic coastal states and correlated well with areas of high atmospheric nitrogen deposition. Concentrations and yields of total nitrogen were highest in the southeastern part of the nation and in parts of the upper Midwest. In the northeast, nitrate was generally the predominant form of nitrogen, and in the southeast and parts of the upper Midwest, organic nitrogen was the dominant form. Concentrations of total phosphorus were generally highest in the Rocky Mountain and Central Plain states.
\end{abstract}

\section{Introduction}

Population growth and industrial activities in the United States during the $20^{\text {th }}$ century have affected, and will continue to affect the quality of the nations water resources. Although natural processes and anthropogenic activities affect water quality in streams, past water-quality studies primarily have been designed to evaluate the anthropogenic affects. To fully evaluate the extent of anthropogenic activities, however, it is also important to describe water quality in streams draining relatively undeveloped environments and to understand the factors that control it. Natural variations in water quality occur among different regions of the nation because of differences in geology, vegetation, and climate, yet standards typically do not account for these differences. For example, some of the most pristine streams in parts of the southeastern United States have dissolved oxygen concentrations that are substandard according to national waterquality criteria (Omernik and Griffith, 1991). Attempting to meet criteria in parts of the nation where they may not be attainable is technically and economically unrealistic. Thus, an understanding of regional patterns in natural water quality provides for a more valid baseline for setting objective, attainable water-quality goals and ultimately will provide a more rigorous tool for separating natural and anthropogenic factors affecting water quality in streams across the nation.

The chemistry of natural waters varies both spatially and temporally and is controlled by factors such as atmospheric deposition, biological activity in soils, and chemical weathering of soils and bedrock (Likens and others, 1977). Approaches used to 
describe regional water-quality characteristics in natural environments include physiographic provinces (Biesecker and Leifeste, 1975), hydrologic drainage basins (Smith, 1969), and ecoregions (Omernik and Gallant, 1986; Hughes and Larsen, 1988; Larsen and others, 1988). Although these frameworks are useful for describing natural spatial variations that occur in different regions of the nation, water quality in natural environments also may be influenced by anthropogenic factors that cross basin and regional boundaries. For example, atmospheric deposition introduces sulfur, nitrogen, base cations, and acidity to relatively undeveloped basins in the northeastern United States (Likens and others, 1996), which in turn may influence the weathering rate and buffering capacity of underlying soils and bedrock (Murdoch and others, 1998; Clow and Mast, 1999; Lawrence and Huntington, 1999). Stoddard (1994) and Williams and others (1996) suggest that the biologic demand for nitrogen has been exceeded by atmospheric inputs in a number of forested basins in the eastern United States and in the Rocky Mountains of Colorado. Atmospheric deposition of nitrogen can account for nearly all the downstream nitrogen load in some Midwestern and Northeastern streams (Smith and others, 1987; Puckett, 1995). Other studies in the northeast have documented the relation between air temperature and nitrogen mineralization and suggest that climate change may be influencing nitrification rates in undeveloped basins where excess nitrogen is accumulating (Murdoch and others, 1998).

The purpose of this paper is to evaluate concentrations and yields of selected nutrients (nitrogen and phosphorus species) in streams draining relatively undeveloped basins across the nation and to identify broad regional and national patterns. No attempt was made to describe concentrations and yields in relation to a defined regional or national framework, such as physiographic province, hydrologic drainage basin, or ecoregion. Nutrient data collected as part of three U. S. Geological Survey (USGS) programs were used for this assessment. To ensure data comparability, differences in selected physical and nutrient characteristics between the basins in each program were assessed. Nutrients were selected for study because of their long-standing role not only as constituents of concern for aquatic health in streams and coastal areas of the nation, but also in ground water. Nitrogen and phosphorus are known to be primary factors that can initiate the excessive growth of algae and macrophytes in freshwater systems. Under the guidelines of the Clean Water Action Plan, the U. S. Environmental Protection Agency (USEPA) is developing regional nutrient criteria for surface-water bodies across the nation. Findings from this assessment will provide baseline data as part of that effort.

\section{Methods}

Nutrient data collected from 85 streams draining relatively undeveloped basins from across the United States were used for this assessment. Basins were selected from three programs of the USGS; the Hydrologic Benchmark Network (HBN), the National Water-Quality Assessment (NAWQA), and the Research Program. Drainage basins of size useful to characterize regional patterns in natural conditions are difficult to find or are not being monitored in many parts of the nation. In order to fill these gaps, some of the basins used for this assessment may be slightly affected by residential development, selective logging, grazing, and other agricultural disturbances. Even with the inclusion of these minimally affected basins, some areas of the nation are poorly represented in this 
assessment. This is especially apparent in the "Corn Belt" region of the upper Midwest and in the Southern Plains states of Kansas, Oklahoma, and Texas (figure 1).

The HBN program was initiated in 1958 to track water-quality trends in streams draining basins free from anthropogenic influence and to study cause and effect relationships between various physiographic, meteorologic, and hydrologic variables (Cobb and Biesecker, 1971). The HBN network is primarily comprised of relatively undeveloped basins encompassing a wide variety of natural environments from across the nation (Clark and others, 1999; Mast and Turk, 1999a,b). To ensure minimal anthropogenic affects, many of the HBN basins are in wilderness areas, national and state parks, national forests, and in areas set aside for scientific study. For this assessment, 43 basins from the HBN network were used, with individual basins ranging in area from about 6.1 to about $2,500 \mathrm{~km}^{2}$.

The USGS NAWQA program, initiated in 1990, was designed to identify and describe major factors that affect observed water-quality conditions over large spatial and temporal scales (Hirsch and others, 1988). Thus, streams sampled as part of the NAWQA represent water-quality conditions influenced by a wide range of land- and water-use conditions. Of the 200 stream sites sampled as part of the NAWQA during 1992-95, 22 drain relatively undeveloped basins. These latter sites were included in this assessment (figure 1). The range in area of NAWQA basins included in this study is similar to the range in area of the $\mathrm{HBN}$ basins, 18 to about $2,700 \mathrm{~km}^{2}$.

The 20 USGS research basins used in this assessment were selected from the Water, Energy, and Biogeochemical Budgets (WEBB) program (USGS, 1999a), the Long Term Ecological Research (LTER) program, and other USGS research (O. Bricker, D. Burns, P. Murdoch, and K. Rice, USGS, written commun., 1999). The research basins included in this assessment are predominantly located in the Appalachian and Rocky Mountains (figure 1). The periods of data collection for the research basins varied, but all research data used for this assessment were collected during water years (October 1 to September 30) 1982-97. The primary focus of study in the research basins used in this assessment is the affects of atmospheric deposition on biogeochemical cycling within small, undisturbed watersheds. The research basins used in this assessment range in size from 0.1 to about $22 \mathrm{~km}^{2}$ and are about 1-2 orders of magnitude smaller than the NAWQA and HBN basins.

Samples from most basins were collected on a weekly to bimonthly schedule. Research basins typically had the highest sampling frequency while HBN basins typically had the lowest. Samples from all of the basins were analyzed for nutrient concentrations at either the USGS National Water Quality Laboratory (NWQL) in Arvada, Colorado or USGS research laboratories. Analyses of samples collected at NAWQA and HBN basins included:

- Dissolved nitrate plus nitrite as nitrogen (nitrate),

- Dissolved ammonia plus ammonium as nitrogen (ammonia),

- Dissolved orthophosphate as phosphorus (orthophosphate), and

- Total phosphorus.

In addition, concentrations of total nitrogen were computed as the sum of nitrate and total Kjeldahl nitrogen (ammonia plus organic nitrogen). For the research basins, only nitrate data were used in this assessment. 
Nutrient concentrations generally vary in relation to streamflow. For example, in some areas of the country, concentrations of nitrate and total phosphorus are greatest during high streamflow and are generally smaller during low streamflow (Murdoch and Stoddard, 1992; Mueller and others, 1995). This variability creates some difficulties for data analysis:

- Summary statistics, such as mean concentration, used to characterize a basin might be biased because of variations in sampling frequency during the period of data collection, and

- Comparisons among basins might be biased because of different sampling frequencies and total numbers of samples collected at different basins.

These data issues were overcome by estimating a concentration value for each day of a common period of record and computing a flow-weighted concentration based on the daily estimates. There is a long history of statistical models that have been used to make such estimates. The model selected for this analysis is based on the rating-curve method (Cohn and others, 1989 and 1992; Crawford, 1991). This method uses multiple regression to estimate constituent transport (load or mass discharge) in relation to streamflow and time. Separate regression models were calibrated for each constituent in each basin. The dependent variable in each case was the natural logarithm of the daily constituent load, computed as the product of the sample concentration and the mean streamflow on the day of sampling. The explanatory (independent) variables for each model were selected from a set of potential predictor variables:

- natural logarithm of mean streamflow for the day of sample collection,

- logarithm of streamflow, squared,

- time, in decimal years,

- sine of time, and

- cosine of time.

Because nutrient concentrations included censored values (values less than the method detection limit (mdl)), model coefficients were estimated by the maximumlikelihood method (Dempster and others, 1977; Wolynetz, 1979). In the absence of censored values, the maximum-likelihood method is equivalent to ordinary least-squares regression.

For each nutrient species in each basin, models were calibrated using the natural logarithm of streamflow plus all possible combinations of other variables. For NAWQA basins, the calibration period was 1992-95; for HBN and research basins the calibration period was 1976-97 or whatever data were available within the time period. The best model for each species-basin combination was selected based on the Aikaike Information Criteria (Aikaike, 1981; Judge and others, 1985).

Estimates of logarithms of daily constituent load were computed using the selected model and daily mean streamflow for a period of several water years. Estimates were converted to load values (in kilograms). Bias introduced by this conversion was corrected using the Bradu-Mundlak method (Bradu and Mundlak, 1970; Cohn and others, 1989; Crawford, 1991). For NAWQA basins, loads were estimated for water years 199495. For HBN and research basins, loads were estimated for water years 1990-95, although in some basins data were not collected for the entire period and estimates reflect only a 
subset of those years. Although some annual variability in nutrient concentrations and yields occurred in these basins, the annual variability was relatively small as compared to the annual variability in nutrient concentrations and yields in more intensively developed basins sampled by the NAWQA during 1992-95. The small amount of annual variability in relatively undeveloped basins is probably the result of small, but consistent inputs of nutrients. For this reason, it was deemed that although not all of the basins in this assessment had a complete data record during water years 1990-95, a comparison of basins with slightly different periods of analysis during 1990-95 was appropriate.

Annual loads, in kilograms $(\mathrm{kg})$, were estimated as the sum of the daily loads for each year. Annual yields represent the load per unit area of drainage basin and were estimated as the annual load divided by the contributing basin area, in kilograms per square kilometer $\left(\mathrm{kg} / \mathrm{km}^{2}\right)$. Flow-weighted concentration, in milligrams per liter $(\mathrm{mg} / \mathrm{L})$, was estimated as the total load over the entire estimation period divided by the total stream discharge during the estimation period.

For some of the nutrient species in some basins, concentrations were less than the mdl in almost all of the samples. In these cases, it was not possible to calibrate a regression model; however, this affected only 34 of the 361 combinations of nutrient species and basins. Flow-weighted concentrations for these nutrients in these basins were estimated as less than the mdl; loads and yields for these basins were estimated using a concentration of one-half the mdl.

\section{Results and Discussion}

Flow-weighted concentrations of nutrients in the relatively undeveloped basins varied across the nation, but, in most basins, they were generally low. The median flowweighted concentrations for all basins were $0.020 \mathrm{mg} / \mathrm{L}$, ammonia as $\mathrm{N} ; 0.087 \mathrm{mg} / \mathrm{L}$, nitrate as $\mathrm{N} ; 0.26 \mathrm{mg} / \mathrm{L}$, total nitrogen; 0.010 , orthophosphate as $\mathrm{P}$; and $0.022 \mathrm{mg} / \mathrm{L}$, total phosphorus (table 1). Median flow-weighted nutrient concentrations in the relatively undeveloped basins ranged from 3 times less for ammonia to 13 times less for nitrate as compared to concentrations in samples collected from a variety of land use settings across the nation by the NAWQA program during 1992-95 (USGS, 1999b).

\section{Nitrate}

Flow-weighted concentrations of nitrate in relatively undeveloped basins tended to be highest in the northeastern part of the United States (figure 2). Twelve of 21 basins with flow-weighted nitrate concentrations exceeding $0.21 \mathrm{mg} / \mathrm{L}$ (the $75^{\text {th }}$ percentile value for all basins; table 1) were located in the northeastern or mid-Atlantic coastal states. However, only three of the relatively undisturbed basins had a flow-weighted nitrate concentration that exceeded $0.6 \mathrm{mg} / \mathrm{L}$. The highest flow-weighted nitrate concentration of $0.77 \mathrm{mg} / \mathrm{L}$ was found in the South Fork of the Potomac River in northeastern West Virginia. The southeastern and southwestern parts of the nation, in general, tended to have the lowest flow-weighted nitrate concentrations (figure 2). The median flowweighted concentration of nitrate for all basins, $0.087 \mathrm{mg} / \mathrm{L}$, was exceeded in only one of the 12 basins located in Arizona, California, Nevada, New Mexico, and Utah.

For basins in the northeastern part of the nation, and in Colorado's Rocky Mountains, the above-average concentrations of nitrate were coincident with areas of elevated nitrate concentrations in atmospheric deposition. Precipitation-chemistry data collected in 1994 as part of the interagency National Atmospheric Deposition Program 
(NADP) indicate that volume-weighted concentrations of nitrate in wet deposition exceeded $0.27 \mathrm{mg} / \mathrm{L}$ over the Rocky Mountains in Northern Colorado, a large part of the central plains, and most of the northeastern United States (NADP, 1999) (figure 2). Some areas of Ohio, Pennsylvania, and New York received wet deposition with nitrate concentrations exceeding $0.40 \mathrm{mg} / \mathrm{L}$. The lowest concentrations of nitrate in precipitation were in the western and southeastern parts of the United States (NADP, 1999) where the concentration generally ranged from $0.02-0.27 \mathrm{mg} / \mathrm{L}$. Although some annual variability may occur, NADP data indicate that concentrations and total deposition of nitrogen from wet deposition remained relatively consistent over most of the nation from 1983-94 (Lynch and others, 1996).

The spatial pattern of annual nitrate yields from undeveloped basins across the nation was similar to the pattern of flow-weighted nitrate concentrations (figure 2). Annual nitrate yields correlated well with wet deposition of total inorganic nitrogen (nitrate plus ammonia as N) from the atmosphere (figure 2). Annual deposition of inorganic nitrogen over the entire eastern United States during 1994 exceeded 300 $\mathrm{kg} / \mathrm{km}^{2}$, and in most of the northeastern United States exceeded $500 \mathrm{~kg} / \mathrm{km}^{2}$ (NADP, 1999). For 11 basins in Maryland, New York, Ohio, Pennsylvania, and West Virginia (the area of largest atmospheric deposition of inorganic nitrogen) the annual basin yield of nitrate averaged about $250 \mathrm{~kg} / \mathrm{km}^{2}$. In contrast, the average annual basin yield of nitrate from 12 basins in Arizona, California, Nevada, New Mexico, and Utah (the area of smallest inorganic nitrogen deposition) was only $8.3 \mathrm{~kg} / \mathrm{km}^{2}$. For nearly all basins, annual deposition of inorganic nitrogen exceeded annual nitrate yield indicating that some nitrogen is retained within basins. However, in two Oregon basins annual nitrate yield averaged almost $400 \mathrm{~kg} / \mathrm{km}^{2}$, or more than two times the amount of inorganic nitrogen introduced by wet deposition. Because these two predominantly forested basins are essentially free of anthropogenic effects, excess nitrate yield is probably derived from localized atmospheric inputs or higher rates of organic decomposition within the basin relative to vegetative growth.

Because the HBN, NAWQA, and Research Programs contain basins with dramatically different physical characteristics, comparisons were made to examine the differences in nitrate concentrations and yields between programs. A statistical comparison between programs for drainage basin area, mean streamflow, mean annual runoff, nitrate concentrations, and nitrate yields is shown in figure 3. Although some significant differences $(\mathrm{p}<0.05)$ between programs were apparent for drainage basin area, mean streamflow, and mean annual runoff, differences in flow-weighted nitrate concentrations were not statistically significant ( $\mathrm{p}>0.05)$. However, annual nitrate yield from research basins was significantly larger than yields from $\mathrm{HBN}(\mathrm{p}=0.002)$ and NAWQA $(p=0.049)$ basins. These differences in nitrate yield are primarily attributable to higher annual runoff from research basins. There was no statistically significant difference in annual nitrate yield between NAWQA and HBN basins (figure 3).

\section{Total nitrogen}

Only 4 of 63, or 6 percent, of the relatively undeveloped basins had a flowweighted total nitrogen concentration exceeding $1 \mathrm{mg} / \mathrm{L}$. By comparison, 83 percent of 97 NAWQA basins sampled during 1990-95 in areas dominated by agricultural and urban residential land had a flow-weighted concentration of total nitrogen exceeding $1.0 \mathrm{mg} / \mathrm{L}$ (USGS, 1999b). Flow-weighted concentrations and mean annual yields of total nitrogen 
tended to be largest in basins in the eastern half of the United States, particularly in southeastern basins and four north-central basins in Michigan, Minnesota, and Wisconsin (figure 4). In basins in the northeastern United States, nitrate generally comprised about 70-80 percent of the total nitrogen concentration and annual yield, and in the southeastern and four north-central basins, nitrate generally comprised less than 25 percent of the total nitrogen concentration and annual yield. Organic forms of nitrogen accounted for most of the total nitrogen concentration and annual yield in the southeastern and four northcentral basins. Southeastern and north-central basins also had some of the highest ammonia concentrations of all the relatively undeveloped basins in the nation. Higher concentrations of ammonia in north-central basins probably result from high rates of atmospheric ammonia deposition over large parts of the upper midwest (NADP, 1999). Of the basins for which both total nitrogen and ammonia data were available, Van Swamp in eastern North Carolina had the highest flow-weighted concentration and mean annual yield of total nitrogen $\left(2.6 \mathrm{mg} / \mathrm{L}\right.$ and $840 \mathrm{~kg} / \mathrm{km}^{2}$, respectively) and ammonia $\left(0.10 \mathrm{mg} / \mathrm{L}\right.$ and $33 \mathrm{~kg} / \mathrm{km}^{2}$, respectively).

\section{Total phosphorus}

The median flow-weighted concentration of total phosphorus in the relatively undeveloped basins was $0.022 \mathrm{mg} / \mathrm{L}$, about 5 times less than the concentration threshold, $0.1 \mathrm{mg} / \mathrm{L}$, generally recommended for prevention of nuisance aquatic growth in streams (USEPA, 1986). Of 63 basins analyzed nationwide for total phosphorus only 4, or 6 percent, had a flow-weighted concentration of total phosphorus exceeding $0.1 \mathrm{mg} / \mathrm{L}$. By comparison, 70 percent of 97 NAWQA basins sampled during 1992-95 in areas dominated by agricultural and urban residential land had a flow-weighted concentration of total phosphorus exceeding $0.1 \mathrm{mg} / \mathrm{L}$ (USGS, 1999b). Flow-weighted concentrations of total phosphorus were generally highest in the Rocky Mountain and Central Plain states and parts of the southeast (figure 5). Flow-weighted concentrations of total phosphorus exceeding $0.10 \mathrm{mg} / \mathrm{L}$ occurred in basins of the Dismal River in central Nebraska (0.20 mg/L), Rock Creek in northern Montana $(0.20 \mathrm{mg} / \mathrm{L})$, Big Jacks Creek in southwestern Idaho $(0.15 \mathrm{mg} / \mathrm{L})$, and Saguache Creek in southern Colorado $(0.12 \mathrm{mg} / \mathrm{L})$. In these four basins, orthophosphate, on average, accounted for about 65 percent of the total phosphorus concentration and yield. In contrast, in basins in the southeastern United States, orthophosphate generally accounted for less than 35 percent of the total phosphorus concentration and yield, with organic and particulate forms accounting for the rest. Larger flow-weighted concentrations of total phosphorus in some of the western basins may result from mineral weathering of phosphorus enriched sediments. For instance, the Dismal River, Rock Creek, and Big Jacks Creek basins are underlain by either marine shale or mafic volcanic rocks (Clark and others, 1999) that are typically enriched in phosphorus. Land use factors such as rangeland grazing of cattle may also contribute to higher phosphorus concentrations in some western basins (Clark and others, 1999). Some of the lowest flow-weighted concentrations of total phosphorus were found in the northeastern part of the United States (figure 5). Of the seven basins located in Maine, Massachusetts, New Hampshire, New Jersey, New York, and Pennsylvania, six had flow-weighted concentrations of total phosphorus less than $0.01 \mathrm{mg} / \mathrm{L}$, the mdl for total phosphorus analysis. Annual basin yields of total phosphorus ranged from less than $1 \mathrm{~kg} / \mathrm{km}^{2}$ from a number of basins to $82 \mathrm{~kg} / \mathrm{km}^{2}$ from Gales Creek in Western Oregon. Gales Creek also had the highest mean annual yield of orthophosphate $\left(23 \mathrm{~kg} / \mathrm{km}^{2}\right)$. As 
with total nitrogen, basins in the southeastern part of the United States had above-average concentrations of organic forms of phosphorus and some of the highest mean annual yields of total phosphorus (figure 5). The large fraction of organic forms of nitrogen and phosphorus in southeastern basins probably results from higher rates of organic decomposition as compared to western basins. The difference in flow-weighted total phosphorus concentrations and mean annual yields between NAWQA and HBN basins was not statistically significant.

\section{Conclusions}

The U.S. Environmental Protection Agency has recognized natural variability of nutrient levels throughout the nation and is developing nutrient criteria for protection of surface-water bodies based on regional background conditions. This study provides a description of background conditions for nutrients in a number of relatively undeveloped basins of the United States. These results can be used to determine achievable baseline conditions for nutrients in basins with similar geographic and hydrologic conditions and to evaluate human effects on water quality in more intensively developed basins. To permit a nationally consistent analysis, only data collected by the USGS were used for this study.

Data from 1990-95 indicate that background concentrations and yields of nitrate are controlled more by anthropogenic inputs from the atmosphere rather than natural factors. Concentrations and yields of nitrate were highest in the northeastern and midAtlantic coastal states and correlated well with wet deposition of nitrate and total inorganic nitrogen from the atmosphere. In contrast, background concentrations and yields of total nitrogen and total phosphorus seem to be controlled by natural factors such as the rates of organic decomposition and mineral weathering. Concentrations and yields of total nitrogen were highest in the southeastern part of the nation and in parts of the upper Midwest. Concentrations and yields of total phosphorus were highest in the western and southeastern United States.

Although some national and regional patterns for nutrients were identified in this study, the number of basins was inadequate to define nutrient conditions in any type of established regional framework such as ecoregions or physiographic provinces. Filling in monitoring gaps, such as the upper Midwest and south-central United States may provide necessary data to define regions of similar baseline water-quality conditions. A regional delineation in natural concentrations of nutrients in surface water would be a valuable tool for agencies at the local, regional, and national scale to adopt attainable water-quality goals and management strategies.

\section{References}

Aikaike, H., 1981, Likelihood of a model and information criterion: Journal of Econometrics, v. 16, p. 3-14.

Biesecker, J.E., and Leifeste, D.K., 1975, Water Quality of Hydrologic Bench Marks An indicator of water quality in the natural environment, U.S. Geological Survey Circular 460-E, $21 \mathrm{p}$ 
Bradu, D., and Mundlak, Y., 1970, Estimation in lognormal linear models: Journal of the American Statistical Association, v. 65, no. 329, p. 198-211.

Clark, M.L. Eddy-Miller, C.A., and Mast M.A., 1999, Environmental Characteristics and Water Quality of Hydrologic Benchmark Network Stations in the West-Central United States, U.S. Geological Survey Circular

Clow, D.W., and Mast, M.A., 1999, Long-term trends in stream water and precipitation chemistry at five headwater basins in the northeastern United States, Water Resources Research, v. 35, p. 541-554.

Cobb, E.D, and Biesecker, J.E., 1971, The National Hydrologic Bench-Mark Network, U.S. Geological Survey Circular 460-D, 38 p.

Cohn, T.A., Caulder, D.L., Gilroy, E.J., Zynjuk, L.D., and Summers, R.M., 1992, The validity of a simple statistical model for estimating fluvial constituent loads: An empirical study involving nutrient loads entering Chesapeake Bay: Water Resources Research, v. 28, p. 2353-2363.

Cohn, T.A., Delong, L.L, Gilroy, E.J., Hirsch, R.M., and Wells, D.K., 1989, Estimating constituent loads: Water Resources Research, v. 25, p. 937-942.

Crawford, C.G., 1991, Estimation of suspended-sediment rating curves and mean suspended-sediment loads: Journal of Hydrology, v. 129, p. 331-348.

Dempster, A.P., Laird, N.M., and Rubin, D.B., 1977, Maximum likelihood from incomplete data via the EM algorithm: Journal of the Royal Statistical Society, Series B, v. 39, no. 1, p. 1-22.

Hirsch, R.M., Alley, W.M., and Wilber, W.G., 1988, Concepts for a National WaterQuality Assessment program, U.S. Geological Survey Circular 1021, 42 p.

Hughes, R.M., and Larsen, D.P., 1988, Ecoregions: an approach to surface water protection, Journal of Water Pollution Control Federation, 60(4), p. 486-493.

Judge, C.G., Griffiths, W.E., Hill, R.C., Lutkepohl, H., and Lee, T.C., 1985, The theory and practice of eonometrics: New York, John Wiley and Sons, p. 870-873.

Larsen, D.P., Dudley, D.R., and Hughes, R.M., 1988, A regional approach to assess attainable water quality: An Ohio case study, Journal of Soil and Water Conservation, 43(2), p. 171-176.

Lawrence, G.B., and Huntington, T.G., 1999, Soil-calcium depletion linked to acid rain and forest growth in the eastern United States, U.S. Geological Survey Water Resources Investigations Report 98-4267, 12 p.

Likens, G.E, Bormann, F.H., Pierce, R.S., Eaton, J.S., and Johnson, N.M., 1977, Biogeochemistry of a Forested Ecosystem. Springer-Verlag, New York, 146 p. 
Likens, G.E., Driscoll, C.T., and Buso, D.C., 1996, Long-term effects of acid rain: Response and recovery of a forest ecosystem, Science, v. 272, pp. 244-245.

Lynch, J.A., Bowersox, V.C., and Grimm, J.W., 1996, Trends in precipitation chemistry in the United States, 1983-94 - An analysis of the effects in 1995 of phase 1 of the Clean Air Act Amendments of 1990, Title IV, U.S. Geological Survey OpenFile Report 96-0346, 100 p.

Mast, M.A, and Turk, J.T., 1999a, Environmental characteristics and water quality of Hydrologic Benchmark Network stations in the eastern United States, 1963-95: U.S. Geological Survey Circular 1173-A, 158 p.

Mast, M.A., and Turk, J.T., 1999b, Environmental characteristics and water quality of Hydrologic Benchmark Network stations in the southeastern United States, 196395: U.S. Geological Survey Circular 1173-B, in press

Mueller, D.K, Hamilton, P.A., Helsel, D.R., Hitt, K.J., and Ruddy, B.C., 1995, Nutrients in ground water and surface water of the United States - An analysis of data through 1992, U.S. Geological Survey Water Resources Investigations Report 954031, $74 \mathrm{p}$.

Murdoch, P.S., and Stoddard, J.L, 1992, The role of nitrate in the acidification of streams in the Catskill Mountains of New York, Water Resources Research, v. 28, p. 2707-2720.

Murdoch, P.S., Burns, D.A., and Lawrence, G.B., 1998, Relation of climate change to the acidification of surface waters by nitrogen deposition, Environmental Science and Technology, 32(11), p. 1642-1647.

National Atmospheric Deposition Program, http://nadp.sws.uiuc.edu/isopleths/maps1994/, accessed May, 1999

Omernik, J.M., and Gallant, A.L, 1986, Ecoregions of the Pacific Northwest: Corvallis, Oreg., U.S. Environmental Protection Agency EPA/600/3-86/033 39 p.

Omernik, J.M., and Griffith, G.E., 1991, Ecological regions versus hydrologic units: Frameworks for managing water quality, Journal of Soil and Water Conservation, September-October, p. 334-340.

Puckett, L.J., 1995, Identifying the major sources of nutrient water pollution, Environmental Science and Technology, 29(9), 408-414.

Smith, C.T., 1969, The drainage basin as an historical basis for human activity. In R. Chorley [ed.] Introduction to geographical hydrology. Methuen and Co., London, England, pp. 20-29.

Smith, R.A., Alexander, R.B., and Wolman, M.G., 1987, Water-quality trends in the nation's rivers, Science, v. 235, p. 1607-1615. 
Stoddard, J.L, 1994, Environmental Chemistry of Lakes and Reservoirs: Baker, LA., [ed.], Advances in Chemistry Series 237, American Chemical Society:

Washington, DC, 1994; pp. 223-84.

U.S. Environmental Protection Agency, 1986, Quality criteria for water-1986: U.S. Environmental Protection Agency report EPA 440/5-86-001 [variously paged].

U.S. Geological Survey, 1999a, http://wwwrvares.er.usgs.gov/nrp/webb.html.

U.S. Geological Survey, 1999b, The quality of our Nations's waters- nutrients and pesticides: U.S. Geological Survey Circular 1225, 82 p.

Williams, M.W., Baron, J.S., Caine, N., Sommerfield, R., and Sanford, R. Jr., 1996, Nitrogen saturation in the Rocky Mountains, Environmental Science and Technology 30(2), pp. 640-646.

Wolynetz, M.S., 1979, Algorithm 139-Maximum likelihood estimation in a linear model with confined and censored data: Applied Statistics, v. 28, p. 195-206. 
Table 1 - Statistical summary of flow-weighted nutrient concentrations and mean annual nutrient yields for relatively undeveloped stream basins in the United States. Values are based on available data for water years 1990-95. Basin locations are shown in figure 1. Note: for Research basins, only data for nitrate concentrations and yields were available. 5/4/2001: 90 th percentile values for nutrient concentrations were added to the table.

\begin{tabular}{|c|c|c|c|c|c|c|c|}
\hline \multirow[b]{2}{*}{ Basins } & \multirow{2}{*}{$\begin{array}{c}\text { Number of } \\
\text { basins }\end{array}$} & \multirow{2}{*}{$\begin{array}{l}\text { Mini- } \\
\text { mum }\end{array}$} & \multicolumn{3}{|c|}{ Percentile } & \multirow[b]{2}{*}{$90^{\text {th }}$} & \multirow{2}{*}{$\begin{array}{l}\text { Maxi- } \\
\text { mum }\end{array}$} \\
\hline & & & $25^{\text {th }}$ & $50^{\text {th }}($ median $)$ & $75^{\text {th }}$ & & \\
\hline \multicolumn{8}{|c|}{ Flow-weighted concentration, in milligrams per liter } \\
\hline & \multicolumn{7}{|c|}{ Dissolved ammonia, as $\mathrm{N}$} \\
\hline All & 65 & $<0.01$ & 0.016 & 0.020 & 0.026 & 0.039 & 0.10 \\
\hline HBN & 43 & $<0.01$ & 0.015 & 0.019 & 0.026 & 0.041 & 0.058 \\
\hline \multirow[t]{2}{*}{ NAWQA } & 22 & 0.010 & 0.020 & 0.020 & 0.030 & 0.030 & 0.10 \\
\hline & \multicolumn{7}{|c|}{ Dissolved nitrate+nitrite, as $\mathrm{N}$} \\
\hline All & 82 & $<0.01$ & 0.040 & 0.087 & 0.21 & 0.43 & 0.77 \\
\hline $\mathrm{HBN}$ & 41 & 0.020 & 0.036 & 0.075 & 0.14 & 0.27 & 0.49 \\
\hline NAWQA & 21 & 0.010 & 0.050 & 0.080 & 0.17 & 0.27 & 0.77 \\
\hline \multirow[t]{2}{*}{ Research } & 20 & $<0.01$ & 0.020 & 0.15 & 0.40 & 0.52 & 0.73 \\
\hline & \multicolumn{7}{|c|}{ Total nitrogen } \\
\hline All & 63 & 0.10 & 0.20 & 0.26 & 0.50 & 0.72 & 2.6 \\
\hline $\mathrm{HBN}$ & 41 & 0.10 & 0.19 & 0.24 & 0.52 & 0.69 & 1.1 \\
\hline \multirow[t]{2}{*}{ NAWQA } & 22 & 0.20 & 0.20 & 0.32 & 0.49 & 1.00 & 2.6 \\
\hline & \multicolumn{7}{|c|}{ Dissolved orthophosphate, as $\mathrm{P}$} \\
\hline All & 65 & $<0.01$ & $<0.01$ & 0.010 & 0.011 & 0.022 & 0.13 \\
\hline $\mathrm{HBN}$ & 43 & $<0.01$ & $<0.01$ & $<0.01$ & 0.010 & 0.021 & 0.13 \\
\hline \multirow[t]{2}{*}{ NAWQA } & 22 & $<0.01$ & $<0.01$ & 0.010 & 0.014 & 0.023 & 0.074 \\
\hline & \multicolumn{7}{|c|}{ Total phosphorus } \\
\hline All & 63 & $<0.01$ & 0.014 & 0.022 & 0.037 & 0.091 & 0.20 \\
\hline $\mathrm{HBN}$ & 41 & $<0.01$ & 0.014 & 0.020 & 0.030 & 0.085 & 0.20 \\
\hline NAWQA & 22 & 0.010 & 0.013 & 0.037 & 0.052 & 0.092 & 0.12 \\
\hline \multicolumn{8}{|c|}{$\begin{array}{c}\text { Mean annual yield, in kilograms per square kilometer } \\
\text { Dissolved ammonia, as N }\end{array}$} \\
\hline All & 65 & $<1.0$ & 4.4 & 8.1 & 12 & & 33 \\
\hline $\mathrm{HBN}$ & 43 & $<1.0$ & 4.6 & 8.1 & 12 & & 33 \\
\hline NAWQA & 22 & $<1.0$ & 4.1 & 7.8 & 13 & & 33 \\
\hline \multicolumn{8}{|c|}{ Dissolved nitrate + nitrite, as $\mathrm{N}$} \\
\hline All & 82 & $<1.0$ & 11 & 26 & 87 & & 580 \\
\hline HBN & 41 & 1.0 & 11 & 23 & 39 & & 380 \\
\hline NAWQA & 21 & $<1.0$ & 10 & 27 & 79 & & 580 \\
\hline Research & 20 & $<1.0$ & 13 & 110 & 290 & & 510 \\
\hline \multicolumn{8}{|c|}{ Total nitrogen } \\
\hline All & 63 & $<1.0$ & 45 & 86 & 220 & & 840 \\
\hline HBN & 41 & 2.1 & 50 & 94 & 170 & & 560 \\
\hline NAWQA & 22 & $<1.0$ & 30 & 62 & 280 & & 840 \\
\hline \multicolumn{8}{|c|}{ Dissolved orthophosphate, as P } \\
\hline All & 65 & $<1.0$ & 1.6 & 2.8 & 4.8 & & 23 \\
\hline $\mathrm{HBN}$ & 43 & $<1.0$ & 1.6 & 3.1 & 4.7 & & 10 \\
\hline NAWQA & 22 & $<1.0$ & 1.2 & 2.7 & 5.4 & & 23 \\
\hline \multicolumn{8}{|c|}{ Total phosphorus } \\
\hline All & 63 & $<1.0$ & 4.8 & 8.5 & 12 & & 82 \\
\hline $\mathrm{HBN}$ & 41 & $<1.0$ & 4.7 & 7.5 & 11 & & 28 \\
\hline NAWQA & 22 & $<1.0$ & 5.1 & 11 & 25 & & 82 \\
\hline
\end{tabular}




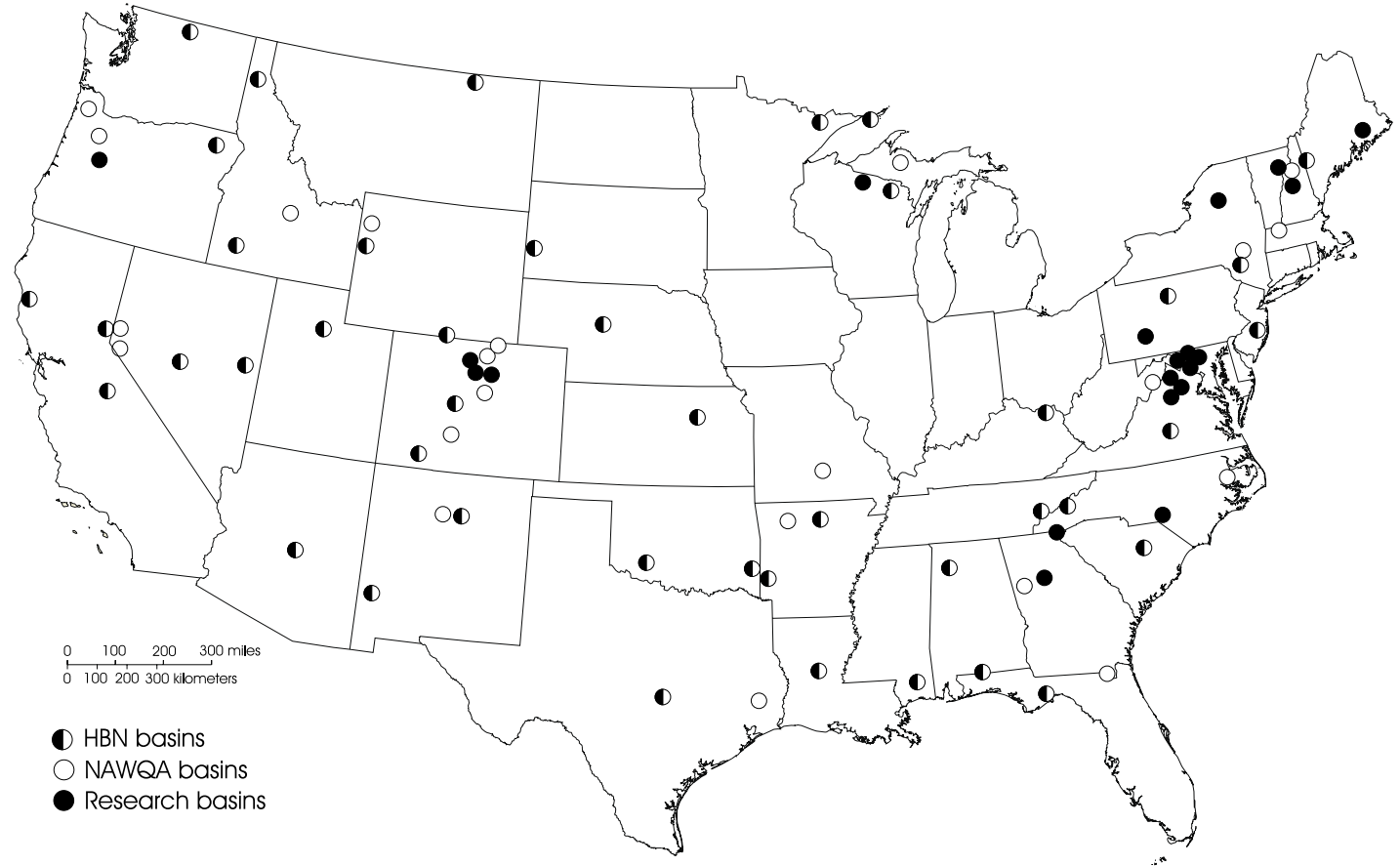

Figure 1 - Location of Hydrologic Benchmark Network (HBN), National Water-Quality Assessment (NAWQA) and research sites used for assessment of nutrient concentrations and yields in relatively undeveloped stream basins of the United States. 

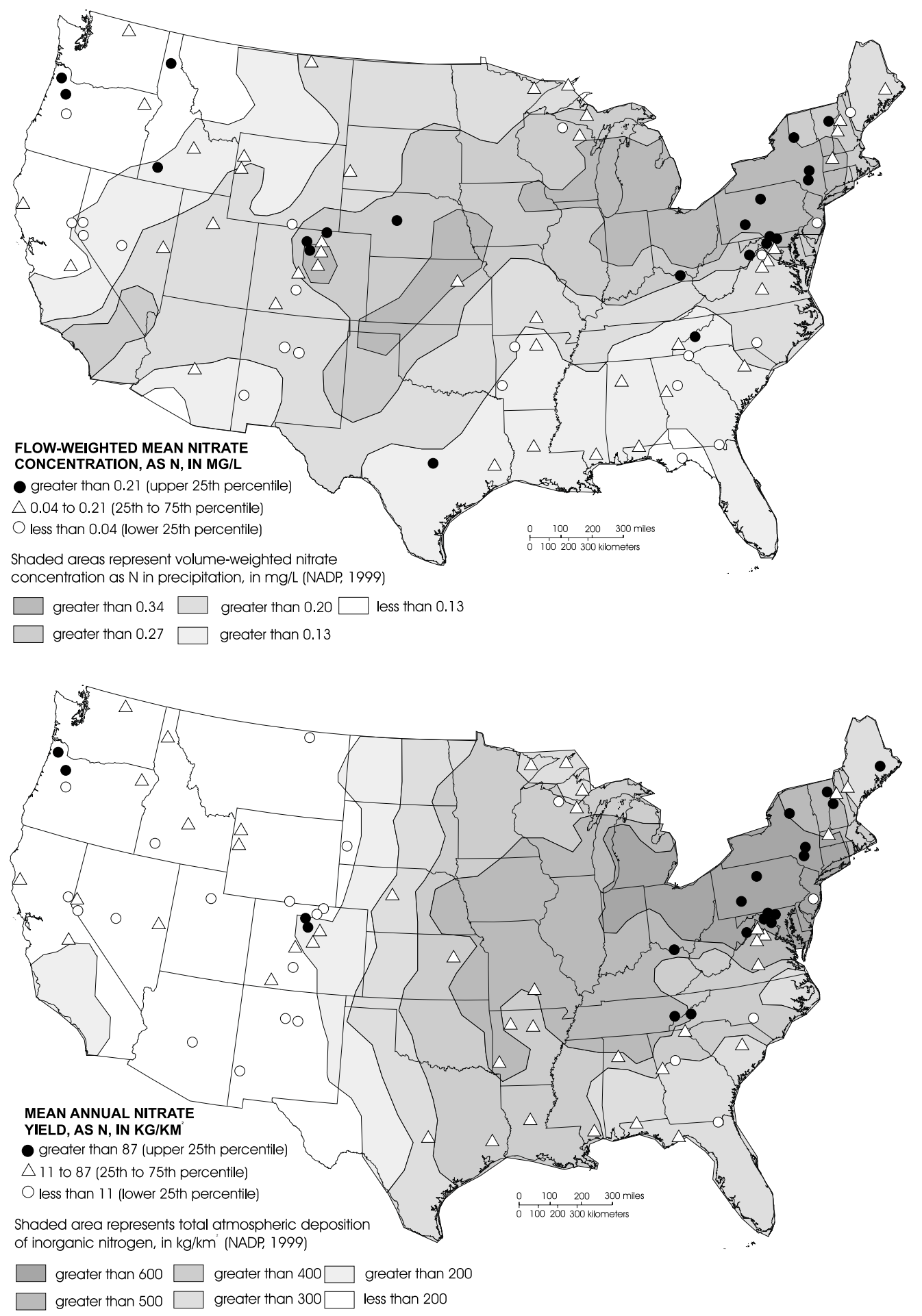

Figure 2 - Flow-weighted concentrations and mean annual yields of nitrate in relatively undeveloped HBN, NAWQA, and research basins and their relation to atmospheric deposition of nitrogen. Basin concentration and annual yield values are based on available data for water years 1990-95. Atmospheric deposition data are from 1994. 

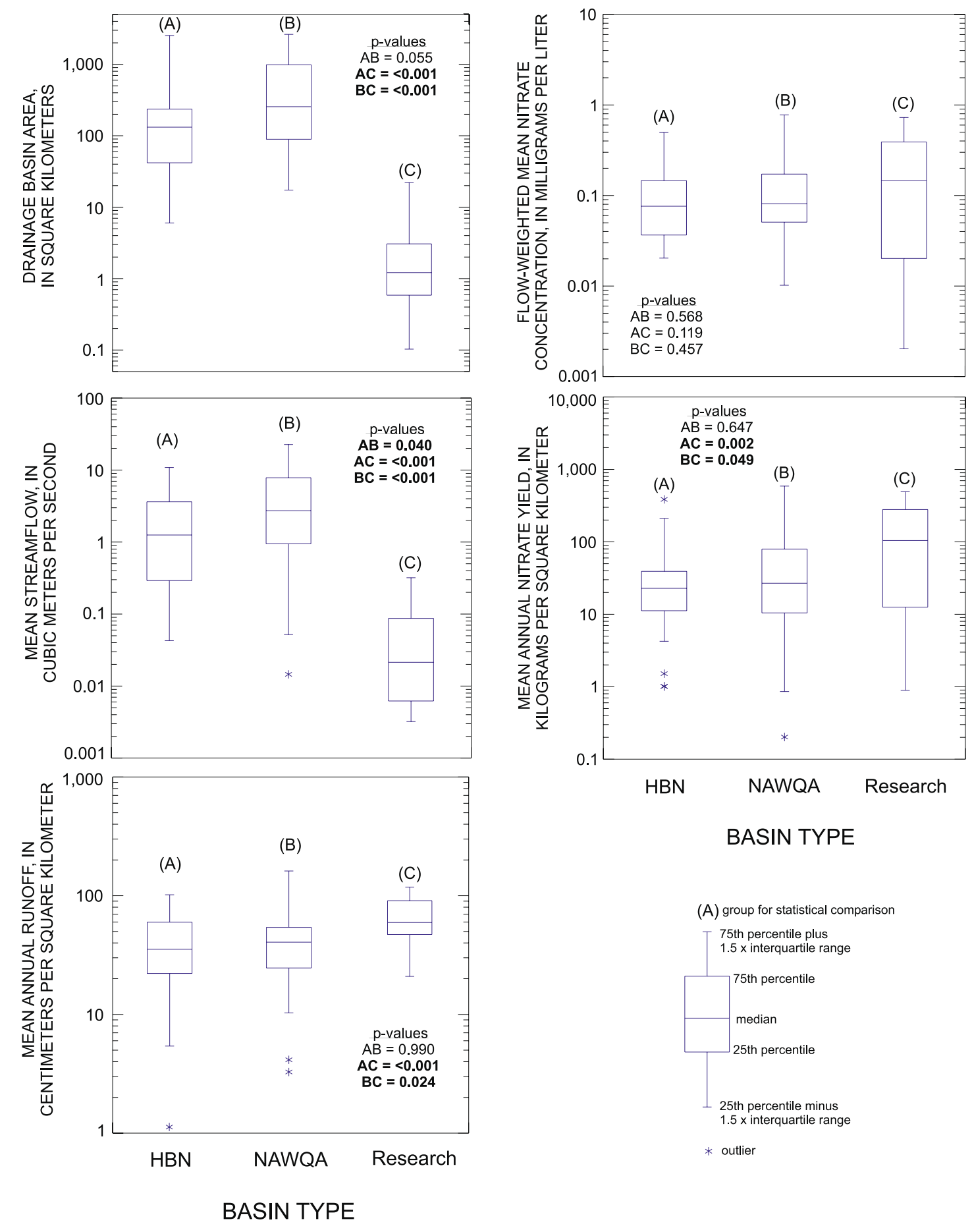

Figure 3 - Physical and hydrologic characteristics and flow-weighted nitrate concentrations and mean annual yield in HBN, NAWQA, and research basins. Values are based on available data for water years 1990-95. P-values of less than 0.05 (bolded) indicate a significant difference between basin type using a Wilcoxon signed-rank test at a 95 percent confidence level. 

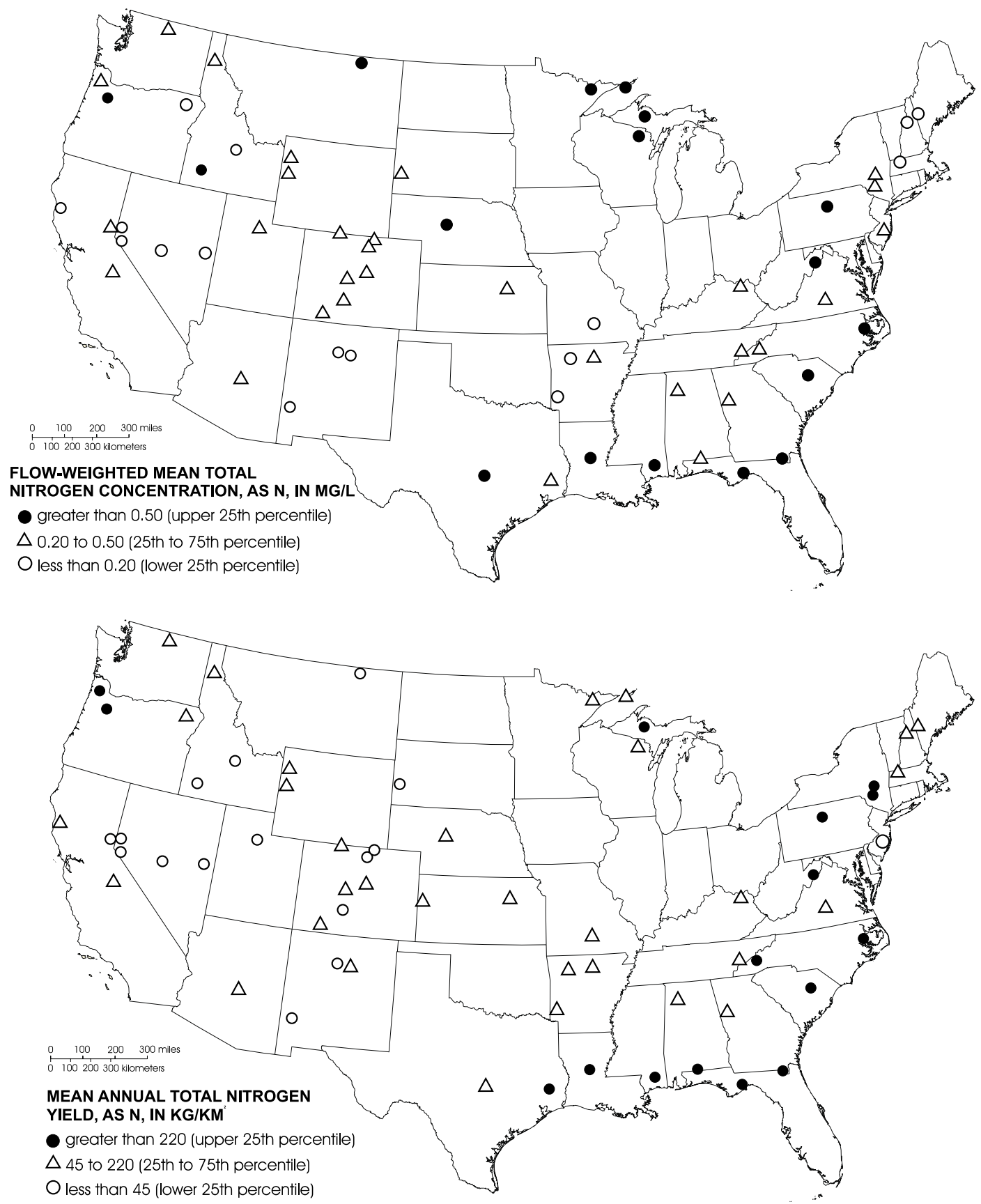

Figure 4 - Flow-weighted concentrations and mean annual yields of total nitrogen in relatively undeveloped HBN and NAWQA BASINS of the United States. Values are based on available data for water years 1990-95. 

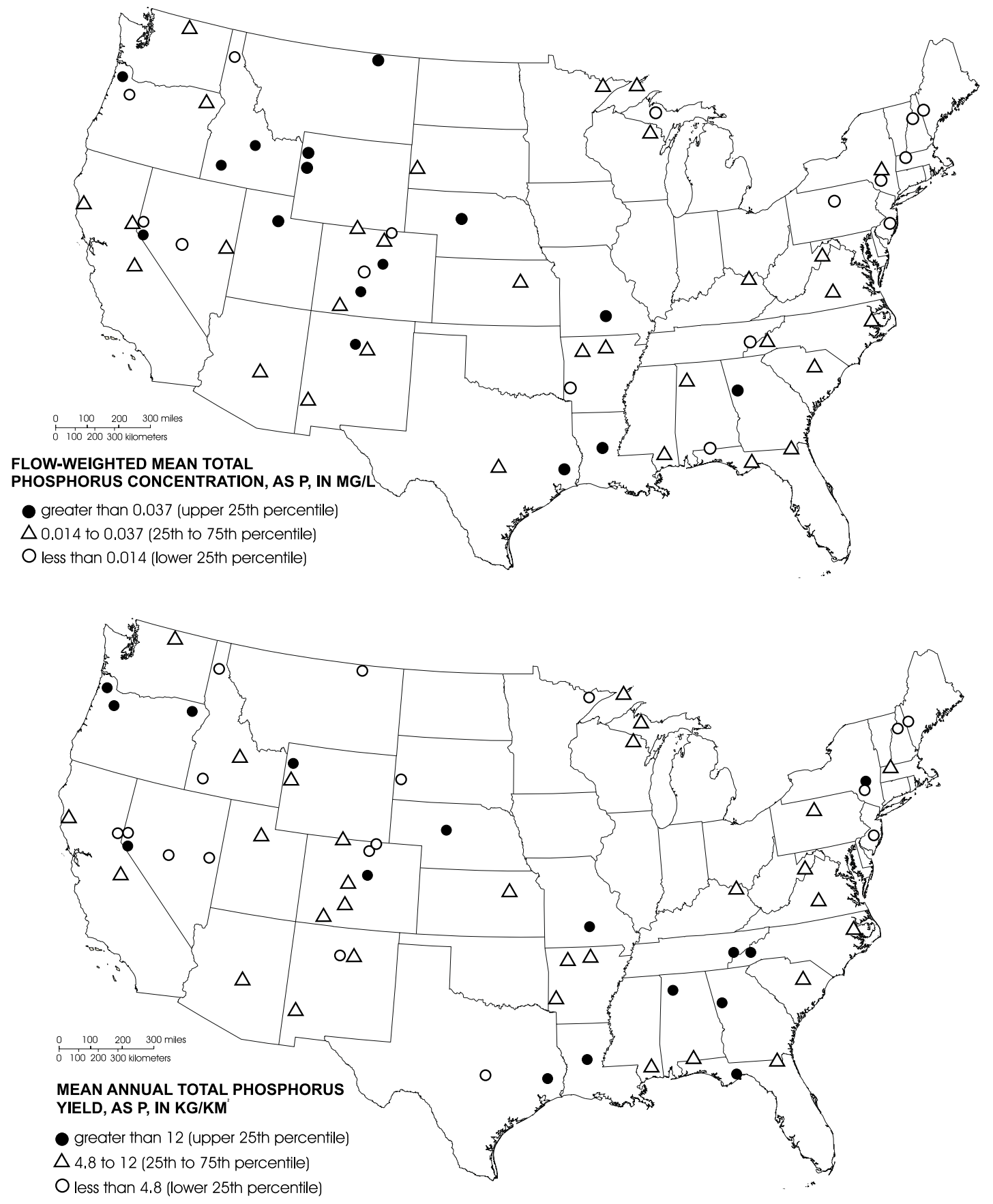

Figure 5 - Flow-weighted concentrations and mean annual yields of total phosphorus in relatively undeveloped HBN and NAWQA basins of the United States. Values are based on available data for water years 1990-95. 